\title{
The Scientific Agricultural Society of Finland 80 Years the 2nd December, 1989
}

The Scientific Agricultural Society of Finland was founded the 2nd December, 1909. At the turn of the century the foundation of a great number of Finnish scientific societies can be seen as a part of the prevalent emphasis on national self-determination at a time when the striving for Russification fell strict on the Autonomous Grand Duchy of Finland. The events in the course of history have violently shaken both our country and its people in 1917, when Finland became an independent republic and in the following 80 years as well, and this has been reflected in the activities of our Society.

The goals of the Society were defined to be the forwarding of the agricultural research and contacts with the research workers on related sciences at home and abroad. The essential part of the activities of the Society has consisted of six or seven annual meetings with lectures and the publication of studies.

In 1911 the Society introduced two series of publications; "Publications of the Scientific Agricultural Society of Finland" and the scientific series "Abhandlungen der Agrikulturwissenschaftlichen Gesellschaf in Finnland." In 1928 the name of the German series was changed to "Acta Agralia Fennica" and English, German, Swedish and Finnish were the chosen publication languages. The following year the Society began the regular publication of the " Journal of the Scientific Agricultural Society of Finland"' in English. At the beginning of 1973 the two publications were merged to form one comprehensive series under the name of the latter, which in 1984 was finally changed to "Journal of the Agricultural Science in Finland”. The number of published annual volumes of the Journal is now 61 , each volume consisting of four to six journals with the edition of 1000 copies including 392 exchange copies.
At regular intervals negotiations have been carried on to unite the above mentioned series with "Annales Agriculturae Fenniae" of the Agricultural Research Center but so far they have failed to bring about any settlement. At the moment discussions are in progress to concentrate the Nordic agricultural scientific publication by intensifying the series "Acta Agricultural Scandinavica" and dividing it into subseries. The prerequisite may be the finishing of some national series on the field in the Nordic countries.

Earlier the Society participated in arrangements of the annual Agricultural Weeks started in the twenties. Since 1981 it has had the whole responsibility for the two-day Scientific Agricultural Seminar in Helsinki. Next March the 10th seminar will be arranged with the theme "New Challenges to Agriculture and Research".

At the beginning of this year our Society had 670 members and nine honorary members: Pellervo Saarinen and Nils Westermark, called in 1974, Juhani Paatela, K.U. Pihkala, Alpo Reinikainen, Martti Salonen and Samuli Suomela, in 1979, and Veikko Brummer and Kaarlo Kallela, in 1984. Five honorary members were called at the 80th anniversary meeting; Paavo Kaarlehto, Kalle Maijala, Yrjö Pessi, Viljo Puustjärvi and Viljo Ryynänen.

Surveys of the activities of the Scientific Agricultural Society have been made at the 25th (Acta Fenniae nr 31, 1943) and 60th (J. Sci. Agric. Soc. Finl. 45; 1-11) anniversaries. In 1959 the jubilee volume of 407 pages on the fifty years' activities was published. In this issue the research in agricultural sciences in Finland in the 1970's and 1980's is reported.

\section{Eeva Tapio}

